\title{
KAJIAN TASAWUF DALAM GUGURITAN SINOM GURINDA PANGRASA KARYA RADEN HAJI MUHAMAD SYU'EB (Analisis Struktural dan Hermeneutik)
}

\author{
Dwi Alia \\ dea moetz88@yahoo.com
}

\begin{abstract}
Abstrak
Penelitian ini dilatarbelakangi oleh masih kurangnya penelitian mengenai kajian tasawuf dalam naskah guguritan. Penelitian ini bertujuan untuk mengkaji tasawuf pada naskah guguritan dengan menggunakan analisis struktural dan hermeneutik. Berdasarkan hasil penelitian, didapatkan beberapa hal berikut:1) dari hasil analisis struktural pada naskah guguritan ini, terdapat 2 bait yang tidak sesuai dengan aturan guru gatra pupuh Sinom yaitu pada bait ke-3 dan bait ke-58. Menurut aturan guru wilangan dalam pupuh Sinom, naskah guguritan ini tidak sesuai dengan aturan yang baku; 2) dari hasil analisis hermeneutik didapatkan isi dari guguritan ini adalah menggambarkan hal-hal yang dialami oleh pengarang dalam mencapai hakikat diri untuk ma'rifatullah; 3) AlMaqam dalam istilah tasawuf yang didapatkan dari hasil kajian pada guguritan ini adalah: attaubah, al-zuhud, as-shabr, at-tawakkal, al-ridha, al-mahabbah, dan al-ma'rifah.
\end{abstract}

Kata Kunci: Tasawuf, Guguritan, Struktural, Hermeneutik.

\section{SUFISM ANALYSIS OF GUGURITAN SINOM GURINDA PANGRASA BY RADEN HAJI MUHAMAD SYU'EB: A STRUCTURAL AND HERMENEUTIC ANALYSIS}

\begin{abstract}
This research was motivated by the dearth of research on the study of Sufism of guguritan manuscripts. This main goal was to examine the Sufism concepts in a guguritan manuscript using a structural analysis and hermeneutics. Results reveal the following: $i$ ) the structural analysis on the guguritan manuscript indicates that two stanzas (i.e. the 3rd stanza and 58th stanza do not align with the rules of the guru gatra pupuh Sinom. According to the rules of the guru wilangan in pupuh Sinom, this guguritan manuscript is not in accordance with the standard rules; ii) the hermeneutic analysis indicates that the guguritan describes what the author experienced in reaching the level of ma'rifatullah (acknowledging God); iii) the findings reveal Al-Maqam-related Sufism terms: attaubah, al-zuhud, as-shabr, at-tawakal, ar-ridho, al-mahabbah, and al-ma'rifah.
\end{abstract}

Keywords: Sufism, Guguritan, Structural, and Hermeneutics.

\section{PENDAHULUAN}

Kajian tasawuf kini memang sedang ramai dibicarakan, dan banyak orang yang menyenangi. Tasawuf dikaji bukan di mesjid saja, tapi juga di hotél-hotel mewah. Tasawuf bukan saja dimiliki oleh sekelompok yang belajar di mesjid kecil di perkampungan, tapi juga sudah berada di ruangan orang kota. Yang menjadi sebab adalah kehidupan modern yang membawa manusia pada dehumanization of men, dehumanisasi manusia. Manusia bukan semakin beradab, tapi manusia semakin hilang 
nilai-nilai kemanusiaannya. Sudah tidak terlihat lagi satu hal yang membedakan manusia dengan makhluk lainnya. Proses dehumanisasi manusia terjadi, ketika manusia melupakan tujuan hidupnya, dan manusia kehilangan cinta. Tasawuf ada untuk menjadi pengingat dan ilmu yang sepenuhnya didasarkan pada cinta, dengan rahman dan rahim Allah SWT. Kajian tasawuf pada naskah guguritan "Sinom Gurinda Pangrasa" karya Raden Haji Muhamad Syu'eb ini, merupakan salah satu cara untuk menyebarluaskan tasawuf di masyarakat.

Naskah ini merupakan naskah dalam huruf Pegon, yang ditransliterasi (alih huruf) pada huruf Latin untuk mempermudah dalam proses membaca serta menganalisis naskah tersebut. Dari hasil transliterasi serta membaca dengan teliti naskah guguritan karya Raden Haji Muhamad Syu'eb, perlu adanya analisis yang lebih mendalam pada naskah tersebut. Naskah guguritan ini perlu diteliti menggunakan analisis secara struktural dan hermeneutik agar ditemui berbagai hal yang terkandung dalam naskah itu. Analisis struktur formal puisi guguritan yang diteliti, memiliki aturan baku yang terikat oleh ketentuan pupuh seperti jumlah baris tiap bait (guru gatra), jumlah suku kata pada tiap baris (guru wilangan), bunyi vokal terakhir pada tiap baris (guru lagu), dan watak pupuhnya. Selain dari struktur formal, diteliti juga struktur naratifnya seperti tema, latar tempat, latar waktu, gaya basa, dan amanat. Dari segi hermeneutik ditelusuri makna yang terkandung dibalik bahasa yang digunakan pengarang, agar didapatkan isi dari guguritan tersebut. Analisis struktural dan hermeneutik yang dilakukan akan mengantarkan pada hal-hal apa saja yang terkandung dalam naskah itu. Salah satu yang diteliti adalah kajian tasawuf yang tergambar dalam guguritan tersebut.

\section{METODE}

Metode yang digunakan dalam penelitian ini adalah metode deskriptif. Hal ini dilakukan untuk mengumpulkan informasi faktual dengan rinci dan menggambarkan adanya ajaran tasawuf dalam guguritan "Sinom Gurinda Pangrasa" karya Raden Haji Muhamad Syu'eb.

Sumber data dalam penelitian ini adalah naskah guguritan dalam bentuk pupuh Sinom, oleh peneliti diberi judul "Sinom Gurinda Pangrasa." Judul ini digunakan oleh peneliti karena isi naskah menjelaskan halhal yang merupakan pengalaman pengarang dalam mengasah batinnya untuk mencapai ma'rifatullah.

Naskah ini merupakan bagian dari naskah kumpulan guguritan karya Raden Haji Muhamad Syu'eb, yang berjumlah 186 halaman. Sedangkan yang diteliti adalah guguritan inti bagian pertama berjumlah 19 halaman, dari halaman 4 sampai pada halaman 22. Naskah guguritan ini terdiri atas 145 bait. Huruf dalam naskahnya adalah huruf Pegon, dan bahasa yang digunakan dalam naskah adalah bahasa Sunda.

\section{HASIL DAN PEMBAHASAN}

Guguritan adalah karangan dalam bentuk terikat (puisi), yang pendek dalam bentuk pupuh (Tamsyah, 1996:59). Menurut Sumarsono (1986:60), guguritan asal katanya dari gurit. Kalau ditelusuri lebih jauh, kata gurit asalnya dari bahasa Sangsekerta grath, artinya menyusun karangan. Dalam bahasa Sunda ada istilah ngagurit atau ngadangding, artinya sama saja menunjukkan pekerjaan membuat atau menyusun karangan dalam bentuk dangding.

Iskandarwassid (2003:119) menyebutkan pupuh merupakan rakitan puisi (bentuk terikat) tradisional, yang terikat oleh berbagai patokan, baik bentuknya ataupun isinya. Dari bentuknya, terikat oleh banyaknya baris pada tiap bait (disebut guru gatra), banyaknya suku kata pada tiap baris (disebut guru wilangan), dan terikat oleh bunyi vokal pada suku kata terakhir tiap baris (disebut guru lagu). Dari isinya, terikat oleh sipat isinya, di antaranya digunakan untuk menggambarkan gembira, sedih (disebut watak pupuh, atau sipat pupuh).

Berdasarkan hasil analisis struktur formal guguritan "Sinom Gurinda Pangrasa" yang didasarkan pada keterangan bahwa guguritan itu terikat oleh berbagai patokan, maka diapat dideskripsikan: 
a. Guru gatra atau jumlah baris tiap bait pada guguritan ini, tidak seluruhnya memenuhi ketentuan pupuh Sinom yaitu 9 baris. Guguritan Sinom Gurinda Pangrasa yang diteliti banyaknya 145 bait. Dari 145 bait, ada 2 bait yang tidak memenuhi ketentuan guru gatra pupuh Sinom yaitu bait ke-3 dan bait ke-58. Dalam dua bait itu hanya ada 8 baris. Hilangnya baris ini ada kemungkinan tidak tertulis oleh pengarang, karena mungkin naskah ini adalah berupa salinan. Alasan lainnya, sengaja tidak ditulis karena tidak menemukan kalimat yang tepat untuk mengisi baris tersebut sesuai dengan aturan guguritan, serta berkesinambungan antar baris yang mewujudkan satu kesatuan bait yang sesuai dan mempunyai makna.

b. Guru wilangan atau jumlah suku kata (silaba) tiap baris, tidak seluruhnya memenuhi ketentuan pupuh Sinom. Baris pada guguritan "Sinom Gurinda Pangrasa" yang guru wilangannya tidak sesuai dengan aturan Sinom, kebanyakan ditemui pada tiap baris ke-5 dan ke-7. Menurut aturan baku, dua baris ini guru wilangannya seharusnya ganjil (tujuh suku kata), tetapi dalam naskah ini kebanyakan digunakan delapan suku kata.

c. Watak yang tergambar dalam guguritan ini sesuai dengan watak pupuh Sinom yaitu menggambarkan kegembiraan atau asmara. Rasa gembira ini tergambar dari isi guguritan yang menceritakan kepuasan batin pengarang dalam mencapai tujuan hidup yakni berada dekat dengan Tuhannya (seperti disebut dalam bait ke-7“...narungtik sirnaning pati, mapay pati nu sampurna.." meneliti akhir hidup, menyusuri akhir hidup yang sempurna..."). Dalam guguritan ini pun, tergambar kecintana kepada Allah Ta'ala (bait ke-31 "sampurna kapangéranan, taya rasa taya ati, taya éling taya hayang, tunggal nya kaula Gusti.." sempurna ketuhanan, tiada rasa tiada hati, tiada ingat tiada ingin, tunggalnya aku Tuhan..”). Dalam guguritan ini juga tergambar ha-hal yang harus dilaksanakan bagi siapa saja yang ingin mencapai kesempurnaan hidup (hirup nu bagja waluya) seperti digambarkan pada bait ke-28 “manusa loba kabisa, bubudi sisip pangarti.." manusia banyak keterampilan, berbudi dan ditambah mengerti.."

Berdasarkan hasil analisis struktur naratif yang terdiri atas analisis tema, latar, gaya bahasa, dan amanat yang terkandung dalam isi guguritan, didapatkan hasil analisis seperti berikut.

\section{a. Tema}

Tema adalah gagasan, ide, atau pikiran utama, yang menjadi dasar dalam karya sastra (Sudjiman,1988:50). Sedangkan menurut Faturrohman (1983:7) tema adalah unsur pokok cerita, yang ditampilkan oleh pengarang dalam karyanya. Tema dalam guguritan ini termasuk pada tema religi, yaitu tema yang cenderung pada persoalan pengalaman religi pengarang secara kongkrit. Tema guguritan ini adalah pengalaman pengarang dalam mencapai kepuasan hidup yakni ma'rifatullah.

\section{b. Latar}

Sudjiman (1995:44) mengungkapkan bahwa segala keterangan, petunjuk, pengacuan, yang berkaitan dengan waktu, ruang, dan suasana terjadinya peristiwa dalam suatu karya sastra. Berdasarkan pada hasil analisis mengenai latar, didapatkan:

1) dari 56 kali latar waktu yang disebut oleh pengarang, digunakan latar waktu berdasarkan titimangsa sebanyak 35 kali (62,5\%), seperti contoh pada bait 142 ada kata "malem Ahad ba'da magrib" malam minggu setelah magrib; latar waktu berdasarkan lamanya sebanyak 16 kali (28,6\%), seperti dalam bait 142 "meunang ngunun lima taun" didapat setelah didiamkan lima tahun; dan latar waktu berdasarkan frekuensi disebut 5 kali (8,9\%), seperti conto pada bait ke-24 ada kata "heuleut beurang heuleut peuting" berselang siang dan malam.

2) Latar tempat yang digunakan dalam naskah guguritan Sinom Gurinda Pangrasa yang termasuk dalam kategori alam nyata yakni hal yang terlihat, tampak oleh penglihatan, 
disebut sebanyak 38 kali (69\%), seperti dalam bait ke-27 "los ka parung los ka gunung" pergi ke parung pergi ke gunung; dan yang termasuk pada alam imajinasi yakni alam yang abstrak, yang tidak tampak oleh penglihatan, disebut dalam naskah guguritan sebanyak 17 kali (31\%), seperti dalam bait ke-3 ada kata 'alam jatnikaning sari' yaitu hal-hl yang sesuai (tepat) dan bagus, dan pada bait ke-26 ada kata 'tegal rasana' yakni rasa yang tanpa batas.

3) Keadaaan ketika berlangsungnya kejadian yaitu rasa yang dialami pengarang dan dirasakan oleh pembaca.

a) Rasa menyesal terlihat dalam bait ke-3, pada kalimat "kapandeurian ngasaan, ngasaan alam hakéki..” telat merasakan, merasakan alam hakiki". Rasa sesal yang dirasakan adalah kenapa baru sekarang menyelami hakikat diri, tidak dari dulu.

b) Rasa bingung terlihat seperti pada bait ke-4 (“..mana cangkang mana eusi, mana mana abdi mana Gusti, mana hina mana agung.."). Kebingungan yang digambarkan adalah kebingungan dalam mencari hakikat diri dan Tuhannya. Kebingungan yang ditambah juga dengan godaan dunya yang menyilaukan.

c) Rasa khawatir tergambar seperti dalam bait ke-27 di bawah ini.

27. "Melang bongana kagémbang,

kateluh baruang angin,

rasana angin-anginan..."

"Khawatir karena terpikat, tergoda pada jebakan angin, perasaan yang tidak tentu.."

Kekhawatiran yang tergambar adalah takut tidak bisa menemukan hakikat dirinya, karena godaan dunia yang begitu banyak, yang membuat diri lupa pada asalnya.

d) Selain dari hal di atas, adapun pada bait yang lainnya menggambarkan keadaan yang ingin dan harus dilakukan oleh manusia untuk mencapai kebahagiaan diri. Misalnya adanya rasa pasrah seperti yang digambarkan pada bait ke-11 dan bait ke-31 berikut.

11. "Rasa sajatining rasa, patina Innalillahi.."

"Rasa sejatinya rasa, meninggalnya Innalillahi..."

31. "Sampurna kapangéranan, taya rasa taya ati, taya éling taya hayang, tunggal nya kaula Gusti.."

Sempurna ketuhanan, tiada rasa tiada hati, tiada ingat tiada ingin, tunggalnya aku dan Tuhan.

Dua bait di atas menggambarkan kepasrahan kepada Tuhan, menerima takdir dari-Nya, tidak mengingat yang lalu dan yang akan datang. Sempurnanya diri dalam beribadah adalah ketika 'tunggal nya kaula gusti', Tuhan dan dirinya bersatu serta dekat dalam pribadinya.

c. Gaya bahasa yang digunakan oleh pengarang di antaranya:

1) Gaya bahasa retorik seperti terlihat pada bait ke-4 dan ke-5.

4. Majazi geus ti baheula, hakéki anyar pinanggih, mana eusi mana cangkang, mana cangkang mana eusi, mana 'abdi mana gusti mana hina mana agung, mana wujud mana 'adam, mana awal mana ahir, mana aing dituduh lain-lainna.

5. Lain Allah lain adam, lain nabi lain wali, lain malaikat enya, lain kama lain kami, lain 'abdi lain gusti, lain hina lain agung, lain ahir lain awal, lain seuneu lain cai, lain eusi hampasna nu dipulungan.

Dalam dua bait ini diulang kata 'mana' dan kata 'lain' hampir pada seluruh baris. Dalam sebagian baris dalam bait ke-139 diulang juga 
kata 'mana' ("mana adam mana Allah, mana sia mana aing, mana napi mana isbat, mana euweuh ieu geuning.."). Hal ini menggambarkan adanya percakapan batin pengarang dalam mencari hakikat dirinya dan Tuhannya.

Dalam beberapa bait juga, ditemukan adanya purwakanti margaluyu yaitu purwakanti yang timbul karena adanya kata di ahir baris, yang diulang kembali pada awal baris berikutnya. Ada juga pada tiap ahir bait, kata terakhirnya diulang kembali pada awal bait berikutnya, seperti terlihat pada bait ke-1 dan ke-2 berikut ini.

\section{Sinom dianggo kawitan, kawitan pisan ngagurit, ngagurit kapusakaan, kapusakaan pribadi, pribadi miriwinci, ciri nu mulus rahayu, rahayu bagja awak, awak kaula pribadi, pribadina nu didadar jadi tembang. \\ 2. Tembang gurinda pangrasa, Pangrasaning sanubari...}

Hal di atas menggambarkan adanya kesinambungan atau keterkaitan antar baris satu dengan yang lainnya, serta kesinambungan dan keterkaitan pada bait yang satu dengan yang lainnya.

2) Gaya basa kiasan. Yang sering muncul dalam guguritan ini adalah gaya basa metafora (membandingkan satu benda dengan benda lainnya karena mempunyai sipat yang sama atau hampir sama) seperti dalam bait ke-2 ada kata "tembang gurinda pangrasa" maksudnya adalah tembang guguritan ini seperti gurinda (batu sebagai alat untuk menajamkan/mengasah pisau,bedog, golok) karena tembang ini merupakan tembang guguritan yang menceritakan pengalaman batin guna mempertajam/ mengasah perasaan.

\section{d. Amanat}

Amanat adalah pesan yang ingin disampaikan oleh pengarang kepada pembaca. Amanat yang didapatkan dari guguritan ini adalah kesempurnaan hidup bisa didapatkan dari kesesuaian dan keseimbangan antara ruh, jiwa, dan raga (badan).

Berdasarkan hasil kajian pada teks naskah guguritan "Sinom Gurinda Pangrasa" karya Raden Haji Muhamad Syu'eb, didapatkan beberapa hal yang berkaitan dengan konsep tasawuf berdasarkan pada beberapa referensi dari para ahli tasawuf yang terkenal. Kata tasawuf mempunyai konotasi pada kebaikan, kesucian hati dari godaan hawa nafsu, memutuskan ketergantungannya pada kehidupan material yang bisa mengganggu hubungannya dengan Tuhan, hidup dalam kezuhudan, serta menyelami kehidupan dalam ibadah sehingga lebih dekat dengan kebenaran yang sejati yaitu Allah SWT. Kajian tasawuf merupakan satu kajian mengenai cara dan jalan yang dilakukan seorang muslim untuk selamanya dekat dengan Tuhannya. Karena syarat utama untuk dekat dengan Tuhan adalah kesucian jiwa, mental, dan spiritual, oleh karena itu seluruh cara dan jalan yang ditempuh harus berpusat pada inti ajaran Islam.

Biasanya, pertanyaan pertama pada kajian tasawuf adalah mengenai posisi manusia dan Allah SWT. Hal ini juga terlihat pada konsep tasawufnya Raden Haji Muhamad Syu'eb dalam guguritan ini, yang terlihat pada bait ke-4 dan bait ke-5.
4. Majazi geus ti baheula, hakéki anyar pinanggih, mana eusi mana cangkang, mana cangkang mana eusi, mana 'abdi mana gusti mana hina mana agung, mana wujud mana 'adam, mana awal mana ahir, mana aing dituduh lain-lainna.

Majazi sudah dari dulu, hakeki baru bertemu, mana isi mana cangkang, mana cangkang mana isi, 
mana 'abdi mana gusti, mana hina mana agung, mana wujud mana 'adam, mana awal mana ahir, mana aku dituduh yang bukan-bukan.

5. Lain Allah lain adam, lain nabi lain wali, lain malaikat enya, lain kama lain kami, lain 'abdi lain gusti, lain hina lain agung, lain ahir lain awal, lain seuneu lain cai, lain eusi hampasna nu dipulungan.

Bukan Allah bukan adam, bukan nabi bukan wali, bukan malaikat, bukan kama bukan kami, bukan 'abdi bukan gusti, bukan hina bukan agung, bukan ahir bukan awal, bukan api bukan air, bukan isi sisanya yang dipunguti.

Beberapa pertanyaan muncul ketika seorang manusia berusaha untuk mencari hakikat diri dan Tuhannya. Mencari jawaban keberadaannya, berusaha untuk memahami rahasia wujudnya. Pencarian ini dilakukan untuk mencapai kesempurmaan. Ibarat suling yang berasal dari rumpun bambu, manusia dijauhkan dari asalnya. Biasanya satu hal yang dijauhkan dari tempat asalnya akan mengalami rasa rindu, rindu untuk kembali lagi ke asal. Seharusnya manusia merasa rindu pada asalnya, seharusnya manusia segera kembali pada cinta Ilahi. Usaha ini memang bukan hal yang mudah, karena berbagai godaan duniawi menyebabkan manusia melupakan diri diri untuk kembali ke asalnya. Seperti dalam bait ke-7 dan ke-8 “... kolot pikun kagémbang $k u$ saliwatan. Saliwatan nya patepang, silo deui silo deui..." orangtua yang pikun tergoda dengan yang sementara. Sementara bertemu, silau lagi silau lagi.." Dengan pengaruh dunia yang menyilaukan, dunia yang hanya sementara tapi penuh dengan berbagai hal yang membuat nyaman, menyebabkan manusia lupa pada hakikat dirinya.

Pada bait ke-16 sampai pada bait ke-20 dijelaskan bahwa pencarian manusia dalam mencari jati diri dan Tuhannya, seperti mencari mutiara yang ada pada saku bajunya sendiri, sulit untuk menemukannya karena terhalang oleh kilauan dunia yang melenakan. Mutiara itu adalah ruh dari nur ilahi yang ditiupkan oleh Tuhan dari saat manusia ada di alam kandungan (4 bulan). Ruh inilah yang dilupakan oleh manusia, karena manusia terlalu terlena hidup di dunia. Seharusnya manusia segera kembali pada ruh-Nya, pada Cinta dari Ilahi. Jangan dinantinanti, jangan merasa diri akan hidup selamanya di dunia, karena hidup yang sebenarnya adalah kelak di aherat yang abadi.

Cara-cara untuk mencapai kesempurnaan (Al-Maqam) yang digambarkan oleh Raden Haji Muhamad Syu'eb:

\section{(1) Maqam Taubat}

Konsep taubat yang tergambar dalam guguritan ini sesuai dengan pendapat Ibn Al-Qayyim Al-Jawziyyah (Rif'i dan Mud'is, 2010: 202), bahwa taubat adalah kembalinya seseorang hamba Allah dengan meninggalkan jalan orang-orang yang dimurkai Allah dan jalan orang-orang yang sesat. Terlihat pada bait ke-2 dan bait ke-3.
3. Tembang gurinda pangrasa, pangrasaning sanubari, bari tembang tutulisan, tulisan diguras-garis, garisan ti pribadi, diawurkeun jadi catur, caturangga sorangan, sorangan ngabulak-balik, balikaneun rasa nu kapandeurian. Tembang yang mengasah perasaan, perasaan sanubari, sambil melantunkan itu ditulis, tulisan digaris-garis, garisan dari pribadi, ditebarkan jadi obrolan, 
obrolan sendiri, sendiri yang membulak-balik, kembalinya rasa yang telat datangnya.

\section{Kapandeurian ngasaan, ngasaan alam hakéki, alam jatnikaning sari, hakékina teu muni, munina dicatur batur, hakéki geus ti baheula, majazi anyar pinanggih, sabalikna teu aya luar jerona. Telat untuk merasakan, merasakan alam hakiki, alam yang mulya, hakikinya tidak jelas, kejelasannya dibicarakan orang lain, hakiki sudah dari dulu, majazi baru bertemu, sebaliknya tidak ada luar dalamnya.}

Bait di atas menjelaskan bahwa tembang ini merupakan pengalaman diri pengarang, perasaan sanubari yang ingin kembali pada ka alam hakeki. Manusia yang menginginkan bertemu dengan hakikat dirinya yang selama ini hanya dibicarakan oleh orang lain. Penyesalan diri karena baru merasakan alam hakeki, alam yang penuh dengan kebahagiaan, yakni hakikat diri yang berada pada ruh ilahi yang telah ditiupkan dari awal oleh Tuhan.

\section{(2) Maqam Zuhud}

Konsép zuhud yang digambarkan dalam guguritan ini seperti pendapat yang diungkapkan oleh para ulama salaf seperti Sufyan Ats-Sauri, Ahmad ibn Hanbal, 'Isa ibn Yunus (dalam Rif'i dan Mud'is, 2010: 209) bahwa zuhud di dunia artinya membatasi cita-cita dan keinginan. Hal ini terlihat pada bait ke-12 hingga bait ke-15. Diri yang tidak menyesali kenapa begini, kenapa begitu, tidak memikirkan dulu dan masa yang akan datang. Memusatkan diri pada hal yang terjadi pada masa kini. Membuat rencana tidak muluk-muluk, ala kadarnya saja, karena di dunia ini tidak ada rencana yang 100\% bisa tercapai dengan mulus. Manusia memang seharusnya terus usaha, tapi tetap Allah yang menentukan. Manusia wajib berusaha, tapi bukan berarti harus menuntut hasilnya terburu-buru. Allah yang mempunyai segala rahasia. "al-insanu bitadbiri Wallahu bitakdiri" manusia yang berencana, dan Allah yang menentukan.

\section{(3) Maqam Sabar}

Konsep sabar yang digambarkan dalam guguritan ini terlihat pada bait ke-21 sampai pada bait ke-25. Kesabaran dalam menyelami hakikat dirinya, dan kesabaran menghadapi hawa napsunya. Di sini dijelaskan bahwa diri sendiri yang memiliki dan bisa menemukan hakikat dirinya, tidak bisa ditemukan oleh orang lain. Dari depan, dari belakang, dari sisi kanan dan kiri tidak bisa ada yang membantu dan tidak ada yang tau, karena diri sendirilah yang menjadi kuncinya. Diri yang tidak terlena oleh dunia, diri yang seimbang antara lahir, batin dan ruhnya. Keseimbangan itu adalah yang dipenuhi dengan sipat dan asma-Nya Tuhan. Dalam bisikan hati, ucapan, dan perbuatan dirinya dalam kehidupan sehari-hari, diisi oleh akhlaqullah (ahlak Allah SWT).

\section{(4) Maqam Tawakkal}

Tawakal adalah berserah diri sepenuhnya kepada Tuhan setelah adanya usaha yang sungguh-sungguh. Selain dari adanya usaha manusia, segala hal tentunya kembali lagi kepada yang memiliki yakni Allah SWT yang memiliki ketentuan. Dalam bait ke-26 dijelaskan bahwa setelah manusia usaha, manusia memasrahkan kepada Tuhannya.

26. "Karasa sanggeus gumelar, kaéling sanggeus ngabukti, kahayang sanggeusna meunang, kari reureuh baé peuting, meuting di indung peuting, nya turun ti Kun Fayakun..."

\footnotetext{
"terasa setelah lahir, sadar setelah terbukti, keinginan setelah mendapatkan, tinggal istirahat saja malam,
} 
bermalam di tengah malam, ya turun dari Kun Fayakun.."

Untuk menyelami hakikat dirinya manusia harus terus berusaha, ketawakalan tidak menjadikannya manusia pasif, tapi justru aktif dan berkembang dalam memahami kehidupan serta menerima kenyataan hidup dengan tepat. Dalam bait ke-28 dijelaskan bahwa manusia yang diharapkan adalah manusia yang banyak keterampilan dan bagus budi pekertinya. Manusia yang selamanya mengaitkan dirinya pada Tuhannya, yakni yang diwujudkan dalam habluminallah dan habluminannas yang baik. Sedikit saja manusia mengingkari, ribuan godaan duniawi akan terus menerus menggoda. Manusia yang diharapkan adalah manusia yang "...eusi gusti waruga kamanusaan, isi Tuhan badan manusia (bait ke-28 baris ke-9)" yaitu manusia yang memiliki sipat-sipat Tuhan, karena manusia ditakdirkan tidak selamanya benar dan tidak selamanya salah tapi ada di antara benar dan salah.

\section{(5) Maqam Rida}

Rida adalah puncak dari kecintaan kepada Tuhan yang didapatkan seorang hamba setelah usahanya maksimal dalam pengabdian dan bermunajat kepada-Nya. Menurut Imam Al-Qusyairi (Rif'i dan Mud'is, 2010: 218), rida adalah tenangnya hati atas katentuan (takdir) Allah Ta'ala serta sesuainya hati dengan apa-apa yang dijadikan oleh Allah Ta'ala. Dalam bait ke-29 dijelaskan manusia yang akan walagri (tidak cacat lahir dan batin) yaitu manusia yang hubungan dengan Tuhannya serta hubungan dengan sesamanya bagus "..hirupna ku kahirupan, usik malik cara tadi, hidupnya oleh kehidupan, bergerak saperti tadi (bait ke-29 baris ke 3\&4)" Selain itu, masih dalam bait itu, di baris selanjutnya ditulis manusi yang tigin (tetap) hatinya adalah yang menjauhkan dirinya dari kemewahan dunia yang berlebihan (hidup sederhana), dan selamanya ingat kepada Allah SWT.

“...huripna tigin ati, cul batur muru ka dapur,

\author{
hirup huripna rata, \\ manusa anu walagri, \\ waras rasa mulia badan sampurna." \\ "hidupnya tetap hati, \\ tidak memperdulikan orang lain, \\ segera ke belakang \\ hidupnya rata, \\ manusia yang bagus lahir batinnya, \\ bagus perasaannya mulia badan sempurna" \\ (pada 29).
}

Seterusnya dalam bait ke-30 dijelaskan sempurnanya kemanusaan adalah manusia yang memahami adanya dua akhir yakni akhir hidup di dunia dan akhir nanti yang tidak akan ada akhirnya (abadi). Manusia juga mengalami dua awal, yakni dilahirkan ke dunia setelah dikandung oleh ibu selama sembilan bulan, dan awal nanti ketika dihidupkan kembali oleh Allah SWT yaumul ahir. Hal ini sesuai dengan Firman Allah dalam Al-Quran surat Al-Baqarah ayat 28: "kaifa takfuruna billahi wakuntum amwatan faahyakum summa yumitukum summa yuhyikum summa ilaihi turja'una"(mengapa kamu mengingkari Allah, sedangkan kamu dulu mati (belum ada), kemudian kamu dihidupkan oleh-Nya, kemudian akan dimatikan oleh-Nya, dan akan dihidupkan kembali oleh-Nya, ahirnya kamu kembali kepada-Nya." (QS. 2:28).

Ayat di atas (QS 2:28) mempunyai makna bahwa manusia dulunya tidak ada ('adam). Kemudian manusia diciptakan oleh Allah untuk hidup di alam dunia, menjadi khalifah di bumi. Setelah hidupnya di dunia manusia akan mengalami mati (adanya alam kubur atau alam barzah). Yang selanjutnya adalah manusia nanti akan dihidupkan kembali oleh Allah, akan mengalami hidup kekal yakni di alam aherat kelak. Di akhir ayat ada kalimat "..ahirnya kamu akan kembali kepada-Nya". Kalimat ini mempunyai makna bahwa kembalinya manusia setelah mengalami beberapa fase, manusia akan berpulang kepada-Nya Yang Mahasegalanya. Untuk kembali pada-Nya, yang diharapkan adalah apa yang digambarkan pada bait ke-36 “...malik pasti rodiyatan mardiyatan, kembali 
pasti rodiyatan mardiyatan" yang sesuai dengan ayat 27-30 surat Al-Fajr.

Yaa ayyatuha an-nafsul mutmainnah (27)

Irji'i ila robbiki rodiyatan mardiyyatan(28)

Fadkhuli fii 'ibadi(29)

Wadkhuli jannati(30)

"Wahai jiwa yang tenang! Kembalilah kepada Tuhanmu dengan hati yang rida dan diridai-Nya. Maka masuklah ke dalam golongan hamba-hamba-Ku, dan masuklah ke dalam surga-Ku." (Q.S. Al-Fajr 27-30).

Kemudian masih dalam bait ke-30, manusia mempunyai tugas menjadi 'abdi kepada Tuhannya dan 'abdi kepada sesamanya (habluminallah dan habluminannas). Ada dua 'yang harus disembah' yang harus dibedakan oleh manusia yaitu yang disembah di dunia yakni orangtua untuk anaknya, suami untuk istrinya, pemerintah untuk rakyatnya, dsb. yang artinya hal-hal yang harus dita'ati dan dihormat tetapi selama membawa pada kebenaran. Tuhan (yang patut disembah) yang satu lagi adalah Allah SWT, Tuhan yang hak disembah dan dita'ati segala perintah dan dijauhi segala larangan-Nya. Jika manusia telah memahami hal itu, sudah bisa menempatkan hal tersebut dengan tepat, baru manusia bisa mulus rahayu, mendapat keselamatan diri. Manusia akan menjadi sempurna.

\section{(6) Maqam Mahabbah}

Mahabbah yaitu usaha untuk mewujudkan rasa cinta dan kasih sayang yang dipusatkan kepada Allah Ta'ala. Mahabbah ini mengosongkan hati dari sagalanya, kecuali dari yang dicintai yaitu Allah SWT. Dalam guguritan ini digambarkan dalam bait 31 , bunyinya saperti di bawah ini.

"Sampurna kapangéranan,

taya rasa taya ati,

taya éling taya hayang,

tunggal nya kaula gusti.."

"sempurnanya ketuhanan,

tiada rasa tiada hati,

tiada ingat tiada ingin,

tunggalnya aku dan Tuhan.."
Dari kalimat di atas tergambar diri yang tidak menginginkan apapun, diri yang tidak ingat apapun kecuali kepada Yang Maha Tunggal, yaitu Allah SWT.

\section{(7) Maqam Ma'rifat}

Ma'rifat adalah terbukanya penghalang antara diri dengan Tuhannya. Manunggalnya sipat dan asma-Nya di dalam diri. Setelah manusia paham pada konsep "dua-dua" hal di atas, manusia akan manunggal jeung Gustina, bersatu dengan Tuhan. Konsep manunggal diri dengan Tuhan ini seperti yang pernah dipaparkan oleh Syekh Siti Jenar (Ingsun Sejatining Gusti Allah), Ibnu 'Arabi (Insan Kamil), jeung Al-Hallaj (Ana Al-Haq). Menurut pendapat Ibnu 'Arabi (Kandito, 2011) bahwa manusia yang bisa bersatu dengan Tuhannya yaitu manusia yang termasuk dalam golongan insan kamil, yakni bagi siapa saja manusia yang bisa mencerminkan sipat-sipat Tuhan, mempunyai kesadaran yang tinggi, serta menyadari untuk bersatu dengan hakikat Tuhan. Manusia yang ada dalam tataran insan kamil ini adalah yang diliputi oleh Nur Muhammad, yaitu cahaya awal yang bersumber dari Allah SWT yang menyebabkan diciptakannya makhluk. Nur Muhammad ada sebelum diciptakan Adam dan sering disebut "akal awal", yakni sebab dari penciptaan alam semesta. Dalam kajian sufisme, insan kamil ada dalam maqam ma'rifat. Dalam maqam ini, kehendak ilahi dan kahendak makhluk bertemu. Bertemunya dua kehendak ini yang disebut manunggaling kawula gusti. Konsep ma'rifat ini jelas terlihat pada beberapa bait dalam guguritan ini yaitu dalam bait ke-37 sampai bait ke-40. Dalam beberapa bait ini jelas tergambar bahwa manusa manunggal dengan Tuhannya, '..abdi gusti ngan sahiji, aku Tuhan hanya satu..(bait ke-40 baris ke-5)." Gerakgeriknya manusia merupakan perintah Tuhan.

\footnotetext{
"Kaula di katunggalan, usik aing malik aing, hayang kula meunang kula, teu pédah pahiri-hiri.."

"Aku dalam ketunggalan,
} 
bergerak aku berbalik aku, ingin daku dapat daku, tidak bertolak belakang.." (bait ke-38)

Selain dari Al-Maqam yang dijelaskan di atas, adapun beberapa hal yang harus dijelaskan masih berkaitan dengan kajian tasawuf yang ditemukan dalam guguritan ini. Beberapa konsep penting dalam tasawuf yaitu adanya syari'at, tarekat, hakikat, dan ma'rifat.

\section{(1) Syari'at}

Syariat adalah ajaran-ajaran Islam yang sipatnya lahiriah dalam bentuk legal-formal atau identik dengan fikih (Ali, 2002:29). Dalam tahap ini muslim menyelami dan mengamalkan ajaran-ajaran agamanya sampai pada makna yang tersurat di dalam Al-quran dan hadist Nabi saw. Dalam guguritan ini memang tidak tergambar jelas adanya wacana mengenai syari'at, karena guguritan ini telah jauh membahas pada usaha diri yang berada dalam tahapan hakikat. Tapi dalam bait ke-61, disabitsabit bahwa syariat merupakan jalan untuk mencapai m'arifat “Opat sotéh ngan jalanna, da hiji bawa ngajadi, syareat reujeung torékat, hakékat ma'rifat hiji.." "Empat itu hanya jalannya, karena akan menjadi satu, syari' at dan tarekat, hakikat ma'rifat satu.." Dalam bait ke92 pun ada kalimat "...fiqih syar'a paislaman, ngiring-ngiringkeun ka pasti..." fiqih syar'a keislaman, menggiring ke kepastian.." ini jelas bahwa syari'at merupakan pembuka jalan mencapai ahirat yang pasti.

\section{(2) Tarekat}

Tarekat dalam pengertian yang luas adalah pengalaman syariat secara benar dan utuh. Dalam hal ini, tidak diragukan lagi, syariat yang merupakan aturan-aturan formal keagamaan itu sudah lengkap, tapi untuk mengamalkannya masih diperlukan petunjuk langsung dari seorang guru, utamanya mengenai ibadah-ibadah praktis. Tarekat tidak lebih dari penyempurnaan amalan syariat secara utuh, sehingga syariat tidak saja selaku ajaran teoritis, tapi berupa praktik keagamaan yang bisa mengantarkan pada kesempurnaan hidup.

Dalam guguritan ini terlihat adanya tarekat selaku penyempurna yang mengantarkan pada kesempurnaan hidup. Terlihat pada bait ke-141 dan ke-144, yang bunyinya seperti di bawah ini.

“...pangeusi nu pribadi,

asal nutur galur batur,

tapak rasa juragan,

pangulu nya guru aing.."

“...isi pribadiku,

asalnya menuruti galur orang lain,

tapak rasanya tuan,

penghulu ya guruku..

(bait ke-141)

"Dua kali aing meunang, sakali ti guru aing, kadua rasa sorangan, anu dipedar ku aing, aing bet tambah yakin.."

"Dua kali aku mendapatkan, sekali dari guruku, kadua rasa sendiri, yang dibahas olehku, aku merasa tambah yakin.." (bait ke-144)

Dari dua bait itu, terlihat bahwa pengarang mempunyai seorang guru yang menjadi panutan dalam mencapai kesempurnaan hidupnya. Seorang guru yang mengantarkan dirinya pada keyakinan untuk menyelami hakikat dirinya yang akan membawa pada m'arifatullah.

\section{(3) Hakikat}

Selain dari aturan-aturan legal-formal dalam bentuk syari' at, ada aturan-aturan yang sipatnya batini yang mempunyai tujuan untuk menyucikan kalbu manusia. Jika amal-amal syari'at lebih menekankan pada kualitas lahir, sedangkan hakikat lebih menekankan pada penghayatan batin. Karena itu, tiap amal lahir tidak kosong dari penghayatan batin. Penghayatan batin ini 
yang menjadi tumpuan hakikat.

Keseimbangan antara amalan syariat dan penghayatan hakikat merupakan hal yang mutlak dalam pandangan kaum sufi. Hal ini sesuai dengan ungkapan dari Imam Malik Ibn Anas "Barangsiapa yang bertasawuf tanpa dilandasi oleh pengetahuan fikih, ia telah menjadi zindiq. Barangsiapa yang mengamalkan fikih tanpa dibarengi dengan penghayatan tasawuf, ia telah fasik. Dan barangsiapa yang mengamalkan keduanya, maka ia telah mendapatkan hakikat kebenaran." Dalam ungkapan sufi ada juga perkataan "Syariat tanpa hakikat kosong dan hakikat tanpa syariat batal."

Sebagaiman yang telah dijelaskan sebelumnya, bahwa guguritan ini merupakan penghayatan pada hakikat diri untuk mencapai $m$ 'arifatullah. Dalam guguritan ini terlihat berbagai gambaran penghayatan batin yang harus ditempuh oleh manusia yang berharap kesempurnaan hirup, seperti telah dijelaskan pembahasan Al-Maqam di atas.

\section{(4) M'arifat}

Menurut tasawuf, m' arifat ada dalam akhir pengalaman kesufian. Ketika seseorang telah mampuh syari' at secara benar dan diiringi dengan penghayatan batin secara hakikat, maka dia akan mencapai apa yang disebut m'arifat. Jadi, m'arifat adalah akhir pengalaman batin sufi, di mana dia bisa melihat Tuhannya dengan mata batinnya. M'arifat adalah terbukanya penghalang antara dirinya dan Tuhan. Seperti yang telah dijelaskan dalam maqam m'arifat, bahwa dalam guguritan ini ada kalimat 'abdi gusti ngan sahiji (baris ke-5 bait ke-40). Bersatunya diri dengan Tuhan, menyerapnya diri akan sifat-sifat Tuhan.

\section{SIMPULAN}

Dari pembahasan di atas dapat disimpulkan bahwa dari hasil analisis struktural pada naskah guguritan ini, terdapat 2 bait yang tidak sesuai dengan aturan guru gatra pupuh Sinom yaitu pada bait ke-3 dan bait ke-58. Menurut aturan guru wilangan dalam pupuh Sinom, naskah guguritan ini tidak sesuai dengan aturan yang baku. Hal ini ditemui pada tiap baris ke-5 dan ke-7, dua baris ini guru wilangannya seharusnya ganjil (tujuh suku kata), tetapi dalam naskah ini kebanyakan digunakan delapan suku kata. Dari hasil analisis hermeneutik didapatkan isi dari guguritan ini adalah menggambarkan hal-hal yang dialami oleh pengarang dalam mencapai hakikat diri untuk m'arifatullah. Dari hasil kajian tasawuf mengenai Al-Maqam didapatkan hasil dari guguritan ini adalah: at-taubah, al-zuhud, as-shabr, at-tawakkal, al-ridha, almahabbah, al-ma'rifah.

\section{PUSTAKA RUJUKAN}

Ali, Yunasril. 2002. Jalan Kearifan Sufi Tasawuf Sebagai Terapi Derita Manusia. Jakarta:PT. Serambi Ilmu Semesta.

Faturrohman, Taufik. 1983. Ulikan Sastra Sunda. Bandung:Djatnika.

Iskandarwassid. 2003. Kamus Istilah Sastra. Bandung: Geger Sunten.

Kandito, Argawi. 2011. Pengakuan-Pengakuan Syaikh Siti Jenar. Yogyakarta:Pustaka Pesantren.

Rif'i, A.Bachrun dan H. Hasan Mud'is. 2010. Filsafat Tasawuf. Bandung:CV. Pustaka Setia.

Sudjiman, Panuti. 1988. Memahami Cerita Rekaan. Jakarta:Gramedia. -. 1995. Filologi Melayu. Jakarta:Pustaka Jaya

Sumarsono, Tatang. 1986. Pedaran Sastra Sunda. Bandung:Medal Agung.

Tamsyah, Budi Rahayu. 1996. Pangajaran Sastra Sunda. Bandung: Pustaka Setia.

\section{UCAPAN TERIMA KASIH}

Rasa terima kasih dan penghargaan setinggitingginya penulis sampaikan kepada Prof. Dr. Iskandarwassid, M.Pd. dan Dr. Dedi Koswara, M.Hum. sebagai pembimbing. Selain itu, penulis menyampaikan terima kasih kepada Ketua Prodi Pendidikan Bahasa dan Budaya Sunda SPs UPI dan Ketua Prodi Jurusan Pendidikan Bahasa Daerah FPBS UPI, serta Redaksi Jurnal Lokabasa atas dimuatnya tulisan ini. 